\title{
Dorota Kobus-Ostrowska
}

University of Lodz, Faculty of Economics and Sociology, Institute of Economics

e-mail: dorota.ostrowska@uni.lodz.pl

ORCID: 0000-0001-5004-6478

\section{Anna Miklaszewska}

University of Lodz, Faculty of Economics and Sociology, Institute of Spatial Economics e-mail: anna.miklaszewska@uni.lodz.pl

ORCID: 0000-0001-7797-4047

\section{SOCIO-ECONOMIC SITUATION \\ OF DISABLED PEOPLE IN SELECTED COMMUNES OF LODZ VOIVODESHIP - PRESENTATION OF STUDY RESULTS}

\section{SYTUACJA SPOŁECZNO-EKONOMICZNA OSÓB Z NIEPEŁNOSPRAWNOŚCIAMI W WYBRANYCH GMINACH WOJEWÓDZTWA ŁÓDZKIEGO - PREZENTACJA WYNIKÓW BADAŃ}

DOI: $10.15611 / \mathrm{pn} .2020 .1 .10$

JEL Classification: R2, R21, R210, I3, I310

Summary: The purpose of the article is to present the socio-economic diversity of people with disabilities in selected municipalities of the Lodz region in terms of urban and rural living environments. The analysis discussed in the paper is based on the findings of the pilot surveys conducted on a sample of 119 participants of the Occupational Therapy Workshops (OTW) run between September and December 2018. To verify hypotheses, measurements of diversification were applied, including a comparison of mean values, one-way analysis of variance (ANOVA), and correlation analysis. In this article the authors use to hypothesis: H1; and assume that the respondents are in a similar socio-economic situation. H2. The authors suppose that the level of diversity of conditions is mostly affected by disability certificate period and the degree of disability. Correlation analysis shows that a lower degree of disability goes along with the respondents' higher assessment of the labor market situation.

Keywords: people with disabilities, housing situation, quality of life, standard of living.

Streszczenie: Cel artykułu stanowi prezentacja zróżnicowania sytuacji społeczno-ekonomicznej osób z niepełnosprawnościami w wybranych gminach województwa łódzkiego ze względu na miejsce zamieszkania oraz cechy społeczno-demograficzne badanych. Analizę oparto na wynikach pilotażowych badań kwestionariuszowych przeprowadzonych na próbie 
119 uczestników warsztatów terapii zajęciowej (WTZ) w 4 ośrodkach w terminie wrzesień-grudzień 2018 r. W celu weryfikacji hipotez wykorzystano: porównanie średnich, jednoczynnikową analizę Anova i analizę korelacji. Badania potwierdzają, że mieszkańcy wsi lepiej ocenili warunki mieszkaniowe oraz sytuację finansową swojej rodziny niż osoby z niepełnosprawnością mieszkające $\mathrm{w}$ mieście, a mieszkańcy miast lepiej ocenili sytuację na rynku pracy. Z analizy korelacji wynika również, że im lżejszy stopień niepełnosprawności, tym respondenci korzystniej oceniają swoją sytuację na rynku pracy, lepiej ocenili też swoje warunki mieszkaniowe.

Słowa kluczowe: osoby z niepełnosprawnościami, sytuacja mieszkaniowa, jakość życia, standard życia.

\section{Introduction}

Any analysis of the social and living conditions of disabled people in Poland should take into account their financial situation, housing conditions, and situation on the labour market. The purpose of the article is to present the socio-economic diversity of the situation of people with disabilities in selected municipalities of the Lodz region in terms of urban and rural living environments and to determine the impact of socio-demographic characteristics (i.e. gender, age, place of residence (city/ village), education) and characteristics related to disability (i.e. degree of disability, period for which a disability degree certificate was issued, and type of disability) on the diversity of the level of the socio-economic situation of the respondents. The analysis discussed in the paper is based on the findings of pilot surveys conducted on the sample of 119 participants of the Occupational Therapy Workshops (OTW) run in four centres between September and December 2018. Two OTW centres are located in Tomaszów Mazowiecki, one in Wolbórz, and the other in Rawa Mazowiecka. The workshop participants demonstrated a diversified degree of disability. The paper contributes to the studies on socio-economic situation people with disabilities, including a large number of publications on social security, and the conditions and quality of life (including Borowiecki, 2016; Janoś-Kresło, Komorowska, Skalska, and Słaby, 2016; Koza, 2016; Szarfenberg, 2017).

\section{Socio-economic situation}

The social and economic situation of people with disabilities includes both objective categories which, inter alia, include living conditions and the subjective factors related to the assessment of one's life situation.

The notion of socio-living conditions has evolved over recent decades. In the 1950s and 1960s it referred to social conditions. The measurement included accumulated assets measured by the amount of funds, car or house. At the next stage of evolution a notion this was extended to include a number of new elements, such 
as living conditions and sources of income, which resulted in the development of the notion of socio-living conditions. Nowadays the study on living conditions is an element of the studies on the quality of life, which play a significant role in modern economy, psychology, pedagogy and medical sciences, and their findings provide valuable information for scientists as well as employees of public institutions. In Poland, studies on the quality of life were first undertaken in the 1990s. Although "the notion of the quality of life appeared in the 1960s as an alternative for the financial growth of the quality of life, i.e. the growth of prosperity, which was a primary goal of the social development in those years. (...) the idea of well-being actually extended with the multi-dimensional notion of the quality of life. The notion of well-being was supplemented with a social dimension." (Panek, 2016, p. 14)

Such a definition proves the crucial role that income sources play as a factor impacting the assessment of the respondents' financial situation, which also includes their living conditions, however the benefit a disabled person receives is the most crucial element. Therefore, the paper's title includes the adjective "social" which makes it possible to highlight the fact that any disabled person is entitled to at least one benefit: a social disability pension or disability pension. Thus the notion of living conditions is completed. This is a crucial problem in the quantification of indices in any study. According to A.I. Brzezińska, R. Kaczan, K. Piotrowski and P. Rygielski (Borowiecki, 2016, p. 82), living conditions are defined as all the conditions in which society, social groups, households or individuals live. The concepts of the social minimum and existential minimum (Institute of Labour and Social Studies, referred to as IPiSS) were adopted in Poland to determine living conditions. The social minimum is defined as "a low level of consumption sufficient to meet all the needs at a moderate level," while the existential minimum is a measure of "extreme poverty" and determines the level of income sufficient to meet only the basic needs of the members of a household" (Firlit-Fesnak and Męcina, 2018, pp. 140-141). Thus, given the context of the analyzed issue, the question of the received benefit and related social security, is also significant (Kowalczyk, 2018).

These conditions primarily relate to the financial conditions, existential security. Moreover, living conditions may be analyzed from different perspectives (Antczak, Grabowska, and Polańska, 2018). For example, living conditions in the specific area (country, region) may be analyzed on at least the two planes: 1) with reference to the whole population or 2) with reference to families, given the diversified level of the incomes they generate (Szarfenberg, 2017, p. 32) Thus, the social and living conditions are only a substitute for what is defined as the "quality of life." This category may have an objective as well as a subjective dimension.

J. Rutkowski asserts that the factors shaping these dimensions include subjective factors (values and contents arranged to correspond to the notion of satisfaction from life, expectations, perception of the past and assessment of perspectives, adopted benchmarks, comparison with the past, aspirations) and objective factors (objective reality in which we live, socio-economic and demographic structure 
of the population under study) (Rutkowski, 1990, pp.33-34). In turn, MichalskaŻyła and Starosta indicate that the quality of life in an objective approach, apart from material conditions, is also affected by such categories as health, education, economic activity, social bonds and social relations, the functioning of the state and the natural environment that have not been subjected to analysis in this publication due to the narrow scope of research. On the other hand, the analysis of the quality of life in a subjective dimension is associated with the assessment of the individual's satisfaction with life, which takes into account, above all, its intangible elements such as joy, satisfaction with life as a whole and its specific fields, as well as issues related to mental well-being and experienced emotional states (Michalska-Żyła and Starosta, 2016, p. 63)

The issue of the socio-economic situation of the population is addressed quite extensively in the literature on the subject of quality of life in an objective sense (Komorowska, Kozłowski, and Słaby, 2019; Wyszkowska and Gotowska, 2013; Stiglitz, Sen, and Fitoussi, 2009; Grzega, 2012; Piasny, 1993, pp. 73-93) and in numerous studies and reports (cf. Material and income situation of households of retirees and pensioners and households with older people aged 60 or more in 2016; Incomes and living conditions of the Polish population - EU research report - SILC 2027; Living conditions in Europe - 2018 edition; Income and Living conditions in Europe).

Nevertheless, factors affecting the quality of life can be individual, such as personality and experience. It was also proved that changeability of the life quality depends on age (Zawiślak, 2011), while gender has no significant association with the life quality achieved (Otrębski, 2007; Smoleń and Sękowski, 2008). It is noteworthy that current findings demonstrate that life quality is best explored in the context of differences or affinities between disabled and healthy people (Brantley, Huebner, and Nagle, 2002; Polak and Pomarańska, 2006). This is not, however, the subject of the study presented in this paper. The issue of the socio-economic situation of people with disabilities is also analyzed wider in low-income developing countries.

Given such a situation, it should be emphasized that the research was most frequently fragmentary and selective. Thus the current state of affairs makes it necessary to conduct a comprehensive analysis regarding the social and living conditions of the disabled people. In this article, as emphasized in the introduction, the focus is mainly on the analysis of the material situation of people with disabilities.

\section{Data and methods}

The following questions were framed under the research problem discussed in the paper:

1. What is the diversity of the socio-economic situation of the respondents by place of residence, broken down by village and city?

2. Is the level of diversification of the socio-living conditions of the disabled determined by the degree of disability, the period for which disability certification was issued or selected socio-demographic characteristics? 
The following hypotheses were framed to address the aforementioned questions:

$\mathrm{H} 1$. We assume that the respondents, regardless of their place of residence, taking into account the rural and urban environment, are in a similar socio-economic situation recognized by the dimension of the housing conditions, assessment of the financial situation and the conditions on the labor market.

$\mathrm{H} 2$. We assume that the level of diversification of socio-living conditions is mostly affected by the disability certificate period and the degree of disability.

Statistical calculations were performed using SPSS/ PS IMAGO software.

\subsection{Data}

Critical analysis of literature, the legal acts in force, as well as original and secondary statistical data were used in the study. Pilot surveys conducted in the four OTW centres in the powiat (second level of administrative division in Poland) of Tomaszów Mazowiecki, Rawa Mazowiecka and Piotrków Trybunalski between September and December 2018 provide the basis for empirical analysis. The survey questionnaire comprised 48 questions and was divided into a respondent's profile and four parts: socio-living conditions, civic activity of the disabled persons, social capital, and activity of the disabled on the labour market. To meet the needs of this analysis, the authors focused primarily on the analysis of the data provided in the certificate, i.e. parts 1 and 4 of the questionnaire. The questionnaire included closed-ended questions.

Table 1. Characteristics of the population under study, part 1

\begin{tabular}{|c|c|c|c|c|c|c|c|}
\hline \multicolumn{2}{|l|}{ Sex } & \multicolumn{2}{|l|}{ Age } & \multicolumn{2}{|l|}{ Education } & \multicolumn{2}{|c|}{$\begin{array}{l}\text { Economically active } \\
\text { on the labor market }\end{array}$} \\
\hline characteristics & $\%$ & characteristics & $\%$ & characteristics & $\%$ & characteristics & $\%$ \\
\hline female & 49.6 & $18-24$ & 10.9 & primary and less & 2.5 & $\begin{array}{l}\text { Economically } \\
\text { active }\end{array}$ & 8.4 \\
\hline \multirow[t]{6}{*}{ male } & 50.4 & $25-34$ & 39.5 & lower secondary & 31.1 & \multirow{6}{*}{$\begin{array}{l}\text { Economically } \\
\text { inactive }\end{array}$} & \multirow[t]{6}{*}{91.6} \\
\hline & & $35-44$ & 29.4 & $\begin{array}{l}\text { vocational } \\
\text { lower secondary }\end{array}$ & 15.1 & & \\
\hline & & $45-54$ & 17.6 & $\begin{array}{l}\text { vocational } \\
\text { secondary }\end{array}$ & 34.5 & & \\
\hline & & $55-64$ & 2.5 & $\begin{array}{l}\text { comprehensive } \\
\text { secondary }\end{array}$ & 5.9 & & \\
\hline & & 65 and over & 0 & $\begin{array}{l}\text { vocational } \\
\text { college }\end{array}$ & 5.9 & & \\
\hline & & & & university & 0.8 & & \\
\hline Total & 100 & Total & 100 & Total & 100 & Total & 100 \\
\hline
\end{tabular}

Source: authors' own compilation based on surveys. 
The data given in Table 1 shows that males and females accounted for 50.4\% and $49.6 \%$, respectively in the study group. Persons aged $25-34$ predominated, accounting for $39.5 \%$ of the respondents. The majority had a secondary or lower secondary education: $40.4 \%$ and $31.1 \%$, respectively. A small percentage of the respondents had a university education, primary or less than primary education: $0.8 \%$ and $2.5 \%$, respectively. The vast majority of the respondents are economically inactive.

Table 2. Characteristics of the population under study, part 2

\begin{tabular}{|c|c|c|c|c|c|c|c|c|c|}
\hline \multicolumn{2}{|c|}{$\begin{array}{c}\text { Place } \\
\text { of residence }\end{array}$} & \multicolumn{2}{|c|}{$\begin{array}{c}\text { Location } \\
\text { of occupational therapy } \\
\text { workshops according } \\
\text { to place of residence }\end{array}$} & \multicolumn{2}{|c|}{$\begin{array}{l}\text { Period for which } \\
\text { disability certificate } \\
\text { was issued }\end{array}$} & \multicolumn{2}{|c|}{$\begin{array}{c}\text { Degree } \\
\text { of disability }\end{array}$} & \multicolumn{2}{|c|}{$\begin{array}{c}\text { Kind } \\
\text { of disability }\end{array}$} \\
\hline characteristics & $\%$ & characteristics & $\%$ & characteristics & $\%$ & characteristics & $\%$ & characteristics & $\%$ \\
\hline Town & 57.1 & $\begin{array}{l}\text { Tomaszów } \\
\text { Mazowiecki } \\
\text { and powiat of } \\
\text { Tomaszów } \\
\end{array}$ & 60.5 & $0-6$ months & 0.8 & minor & 5.9 & acquired & 28.6 \\
\hline \multirow[t]{5}{*}{ Village } & 42.9 & $\begin{array}{l}\text { Rawa } \\
\text { Mazowiecka } \\
\text { and powiat of } \\
\text { Rawa }\end{array}$ & 16.8 & up to 1 year & 1.7 & moderate & 46.2 & congenital & 71.4 \\
\hline & & $\begin{array}{l}\text { town and gmina } \\
\text { of Wolbórz }\end{array}$ & 22.7 & 1-3 years & 10.1 & significant & 46.2 & & \\
\hline & & & & 3-5 years & 15.1 & $\begin{array}{l}\text { systemic lack } \\
\text { of data }\end{array}$ & 1.7 & & \\
\hline & & & & indefinite time & 69.7 & & & & \\
\hline & & & & $\mathrm{n} / \mathrm{a}$ & 2.5 & & & & \\
\hline Total & 100 & Total & 100 & Total & 100 & Total & 100 & Total & 100 \\
\hline
\end{tabular}

Source: authors' own compilation based on surveys.

The data given in Table 2 show that town residents predominate slightly in the study group, accounting for $57.1 \%$. The majority of the respondents are residents of Tomaszów Mazowiecki and the powiat of Tomaszów (60.5\%). The residents of Rawa Mazowiecka, the powiat of Rawa, the powiat of Piotrków (Wolbórz town and commune - gmina) were also involved in the survey, accounting for $16.8 \%$ and $22.7 \%$, respectively. The vast majority of the respondents were persons holding disability certificate issued for an indefinite time (69.7\%). Given their disability degree, it is necessary to emphasize that $46.2 \%$ of the respondents have a moderate disability and persons with a significant disability account for the same percentage (46.2\%). Congenital and acquired disability were reported by $71.4 \%$ and $28.6 \%$ of the respondents, respectively. 


\subsection{Methodology of study}

The article used a quantitative approach to data collection and analysis. It takes into account the use of the survey questionnaire as a research tool and statistical analysis as the basis for formulating conclusions. These research methods are quite commonly used in the literature on the subject (Bakula, et al., 2011, pp. 247-253; Mockeviciene and Savenkoviene, 2012, pp. 84-93; Michalska-Żyła and Starosta, 2016, pp. 63-90). To explain the discussed research problem, two sets of variables were distinguished: the dependent variable and explanatory variables.

The socio-economic situation of people with disabilities is the independent variable in synthetic terms, and consists of three specific variables. The first is the housing situation presented as a synthetic index built using reliability analysis (Cronbach's alpha coefficient) from the primary variables listed in Tables 3 and 4. The second is an assessment of the family's financial situation and the third - an assessment of the situation on the labor market. Reliability analysis (Cronbach's alpha coefficient) was also used to construct the synthetic independent variable (socio-economic situation of people with disabilities). In both cases, the primary variables were standardized.

The set of variables explaining the variability of dependent variable (socio-living conditions) comprises two sets of variables: disability-related variables, including

Table 3. Detailed interval and order variables as a part of the 'housing situation' synthetic variable

\begin{tabular}{|l|c|c|c|c|l|}
\hline \multicolumn{1}{|c|}{ Variable } & Mean value & Min. & Max. & $N$ & \multicolumn{1}{c|}{ Comments } \\
\hline Number of rooms in flat/house & $3(2.8)$ & 0 & 6 & 119 & - \\
\hline $\begin{array}{l}\text { Facilities for disabled persons in } \\
\text { an apartment/house }\end{array}$ & $4(4.23)$ & 0 & 5 & & $\begin{array}{l}\text { Number of facilities in an } \\
\text { apartment/house }\end{array}$ \\
\hline $\begin{array}{l}\text { Assessment of the housing } \\
\text { situation of the respondents }\end{array}$ & $4(3.65)$ & 1 & 5 & & $\begin{array}{l}\text { Score at 1-5 scale. where } \\
1 \text { denotes very poor and } \\
5 \text { denotes very good } \\
\text { conditions }\end{array}$ \\
\hline
\end{tabular}

Source: authors' own compilation based on surveys.

Table 4. Detailed nominal variables making up the 'housing situation' synthetic variable

\begin{tabular}{|c|c|c|c|c|c|}
\hline \multicolumn{2}{|c|}{ Right to flat } & \multicolumn{2}{|c|}{$\begin{array}{l}\text { Ownership structure } \\
\text { of occupied flat }\end{array}$} & \multicolumn{2}{|c|}{$\begin{array}{l}\text { Adjustment of occupied flat } \\
\text { to current health condition }\end{array}$} \\
\hline characteristics & $\%$ & characteristics & $\%$ & characteristics & $\%$ \\
\hline lives with family & 65.5 & communal & 1.7 & yes & 75.6 \\
\hline Tenant & 9.2 & council/ rented & 19.3 & no & 24.4 \\
\hline Owner & 25.2 & privately owned & 7.9 & & \\
\hline
\end{tabular}

Source: authors' own compilation based on surveys. 
Table 5. Descriptive statistics of the explained 'socio-living conditions' variable characterized by the housing conditions, assessment of the financial situation, and assessment of the situation on the labor market

\begin{tabular}{|c|c|c|c|c|c|c|c|}
\hline Variable & $\begin{array}{l}\text { Mean } \\
\text { value }\end{array}$ & Mode & Min. & Max. & $\begin{array}{l}\text { Standard } \\
\text { deviation }\end{array}$ & \multirow{3}{*}{$N=119$} & Comments \\
\hline $\begin{array}{l}\text { Synthetic index } \\
\text { of the housing } \\
\text { situation * }\end{array}$ & .0000 & 1.04 & -13.45 & 6.17 & 3.29 & & - \\
\hline $\begin{array}{l}\text { Assessment } \\
\text { of the financial } \\
\text { situation of } \\
\text { family }\end{array}$ & $3.16(3)$ & 3 & 1 & 5 & .79 & & $\begin{array}{l}\text { assessment at } 1- \\
5 \text { scale, where } 1 \\
\text { denotes very bad and } \\
5 \text { very good financial } \\
\text { situation }\end{array}$ \\
\hline $\begin{array}{l}\text { Assessment of } \\
\text { the situation on } \\
\text { the labor market }\end{array}$ & $.63(1)$ & 1 & -1 & 1 & .51 & & $\begin{array}{l}\text { assessment at }-1 \\
-1 \text { scale, where } 1 \\
\text { denotes good and }-1 \\
\text { bad situation on labor } \\
\text { market }\end{array}$ \\
\hline
\end{tabular}

$*$ Cronbach's alpha $=.536$ (Field, 2005, p. 727).

Source: authors' own compilation based on surveys.

Table 6. Descriptive statistics of the 'socio-economic situation of persons with disabilities' synthetic dependent variable

\begin{tabular}{|c|c|c|c|c|c|c|}
\hline \multicolumn{1}{|c|}{ Variable } & Mean & Dominant & Min. & Max. & $\begin{array}{c}\text { Standard } \\
\text { deviation }\end{array}$ & $N$ \\
\hline $\begin{array}{l}\text { A synthetic index of the } \\
\text { socio-economic situation of } \\
\text { people with disabilities * }\end{array}$ & .0000 & .95 & -8.29 & 3.54 & 2.07246 & 119 \\
\hline
\end{tabular}

$*$ Cronbach's alpha $=.521$ (Field, 2005, p. 727).

Source: authors' own compilation based on surveys

degree of disability, the period for which the disability certificate was issued, kind of disability, and selected socio-demographic characteristics, including gender, age, education, and place of residence.

\subsection{Study results}

To verify the hypotheses, the following measurements of diversification were applied: Standard deviation and one-way analysis of variance (ANOVA), and correlation analysis. The research methodology of contingency analysis (including conditions of its application) is described in detail in the literature (e.g. Bedyńska and Brzezicka, 2007; Field, 2005; Howell, 2006; Nowojczyk, 2010; Szymczak, 2010). 
As independent variables bear no characteristics of interval variables. Kendall's tau $\mathrm{b}$ coefficient was applied to estimate the strength of association.

Table 7. Diversification of specific variables included in the socio-economic situation of people with disabilities - synthetic index in terms of place of residence broken down by village and city

\begin{tabular}{|l|c|c|c|c|l|}
\hline \multicolumn{1}{|c|}{ Variable } & $\begin{array}{c}\text { Standard } \\
\text { deviation }\end{array}$ & $\begin{array}{c}\text { Mean } \\
\text { value }\end{array}$ & $N$ & $\begin{array}{c}\text { Standard } \\
\text { error }\end{array}$ & \multicolumn{1}{|c|}{$\begin{array}{c}\text { Place } \\
\text { of residence }\end{array}$} \\
\hline Housing situation & 3.437 & -.5332 & 68 & 3.43685 & town \\
\cline { 2 - 6 } & 2.974 & $\mathbf{. 7 1 0 9}$ & 51 & 2.97449 & village \\
\hline Assessment of financial situation & 1.081 & 2.8971 & 68 & 1.08090 & town \\
\cline { 2 - 6 } & 0.901 & $\mathbf{3 . 2 1 5 7}$ & 51 & .90142 & village \\
\hline \multirow{2}{*}{$\begin{array}{l}\text { Assessment of situation on labor } \\
\text { market }\end{array}$} & 0.481 & .6471 & 68 & .48144 & town \\
\cline { 2 - 6 } & 0.568 & .6078 & 51 & .56845 & village \\
\hline
\end{tabular}

Source: authors' own compilation based on surveys.

The data presented in Table 7 and the one-way ANOVA analysis $(p=.041)$ shows that the diversity of the housing situation of urban residents is greater than that of rural residents. In addition, the diversity of the housing situation is much larger when broken down into rural and urban than in the case of assessing the financial situation and assessing the labor market. As results from Table 7, a high level of homogeneity of the assessment of the financial situation and of the situation on the labour market of the respondents was found.

In addition, the presented analyses show that rural respondents assessed their housing conditions and financial situation considerably higher than their urban counterparts. Similar conclusions were presented by Heffner and Klemens (2012), who noted that living conditions defined as the living space, are assessed higher by rural respondents. "Despite the fact that the number of persons per flat is larger in the village, the space per head is considerably larger there" (Heffner and Klemens, 2012, p. 83), yet statistically significant differences in favour of the urban environment are noted with regard to the assessment of the situation on the labour market $(\mathrm{p}=.001)$.

Table 8. Diversification of the socio-economic situation of people with disabilities synthetic variable by place of residence broken down by village and city

\begin{tabular}{|l|c|c|c|l|}
\hline \multicolumn{1}{|c|}{ Variable } & Standard deviation & Mean value & $N$ & \multicolumn{1}{|c|}{ Place of residence } \\
\hline $\begin{array}{l}\text { Socio-economic } \\
\text { situation }\end{array}$ & 2.16876 & -.2639 & 68 & town \\
\cline { 2 - 5 } & 1.90072 & .3519 & 51 & village \\
\hline
\end{tabular}

Source: authors' own compilation based on surveys.

Table 8 shows that the socio-economic diversity of people with disabilities is slightly larger in cities than in rural areas. However, one-way ANOVA analysis ( $p=$ 0.109 ) proves that these differences are not statistically significant. 
Table 9. Analysis of correlation between specific variables included in the socio-economic situation of people with disabilities independent variable - synthetic index and socio-demographic and disability-related variables

\begin{tabular}{|c|c|c|c|}
\hline $\begin{array}{c}\text { Name } \\
\text { of variable }\end{array}$ & Housing situation & $\begin{array}{l}\text { Assessment } \\
\text { of financial } \\
\text { situation }\end{array}$ & $\begin{array}{c}\text { Assessment } \\
\text { of situation } \\
\text { on the labor market }\end{array}$ \\
\hline \multirow[t]{2}{*}{ Gender } & $p=.570$ & $p=.149$ & $p=.956$ \\
\hline & $\begin{array}{l}\text { Kendall's tau b } \\
\text { coefficient (.043) }\end{array}$ & $\begin{array}{l}\text { Kendall's tau b } \\
\text { coefficient }(-.124)\end{array}$ & $\begin{array}{l}\text { Kendall's tau b } \\
\text { coefficient }(.005)\end{array}$ \\
\hline \multirow[t]{2}{*}{ Age } & $p=.429$ & $p=.038$ & $p=.653$ \\
\hline & $\begin{array}{l}\text { Kendall's tau b } \\
\text { coefficient }(-.055)\end{array}$ & $\begin{array}{l}\text { Kendall's tau b } \\
\text { coefficient }(-.163)\end{array}$ & $\begin{array}{l}\text { Kendall's tau b } \\
\text { coefficient }(-.035)\end{array}$ \\
\hline \multirow[t]{2}{*}{ Education } & $p=.007$ & $p=.060$ & $p=.268$ \\
\hline & $\begin{array}{l}\text { Kendall's tau b } \\
\text { coefficient }(.185)\end{array}$ & $\begin{array}{l}\text { Kendall's tau b } \\
\text { coefficient }(.145)\end{array}$ & $\begin{array}{l}\text { Kendall's tau b } \\
\text { coefficient }(.084)\end{array}$ \\
\hline \multirow[t]{2}{*}{ Place of residence } & $p=.018$ & $p=.078$ & $p=.001$ \\
\hline & $\begin{array}{l}\text { Kendall's tau b } \\
\text { coefficient (.179) }\end{array}$ & $\begin{array}{l}\text { Kendall's tau b } \\
\text { coefficient }(.151)\end{array}$ & $\begin{array}{l}\text { Kendall's tau b } \\
\text { coefficient }(.277)\end{array}$ \\
\hline \multirow[t]{2}{*}{ Kind of disability } & $p=.593$ & $p=.244$ & $p=.872$ \\
\hline & $\begin{array}{l}\text { Kendall's tau b } \\
\text { coefficient }(-.040)\end{array}$ & $\begin{array}{l}\text { Kendall's tau b } \\
\text { coefficient }(-.099)\end{array}$ & $\begin{array}{l}\text { Kendall's tau b } \\
\text { coefficient }(.013)\end{array}$ \\
\hline \multirow{2}{*}{$\begin{array}{l}\text { Period for which disability } \\
\text { certificate was issued }\end{array}$} & $p=.043$ & $p=.172$ & $p=.580$ \\
\hline & $\begin{array}{c}\text { Kendall's tau b } \\
\text { coefficient }(-.146)\end{array}$ & $\begin{array}{l}\text { Kendall's tau b } \\
\text { coefficient }(-.111)\end{array}$ & $\begin{array}{l}\text { Kendall's tau b } \\
\text { coefficient }(-.044)\end{array}$ \\
\hline \multirow[t]{2}{*}{ Degree of disability } & $p=.089$ & $p=.079$ & $p=.004$ \\
\hline & $\begin{array}{c}\text { Kendall's tau b } \\
\text { coefficient }(-.127)\end{array}$ & $\begin{array}{c}\text { Kendall's tau b } \\
\text { coefficient }(-.148)\end{array}$ & $\begin{array}{c}\text { Kendall's tau b } \\
\text { coefficient }(-.239)\end{array}$ \\
\hline
\end{tabular}

Source: authors' own compilation based on surveys.

The analysis of the correlation presented in Table 9 shows that there is a statistically significant relationship between the housing situation and some socio-demographic characteristics, such as education $(p=.007)$ and place of residence $(p=.018)$. The ratio of correlation (Kendal's tau $b$ coefficient $=.185$, respectively) for education, as well as $i(p=.179)$ for the place of residence, demonstrate moderate strength of association between variables. The analysis presented in the paper proves that the better education the respondents had, the better their housing situation. Moreover, analysis of correlation reveals that a better housing situation occurs in the rural environment. There is also a statistically significant relationship between the housing situation and the period of time for which the disability certificate is issued $(p=.043)$. The strength of association between the aforementioned variables is running at the mean level - (Kendall's tau $b=-.146)$. The correlation analysis 
shows that the shorter the period of time for which the disability certificate is issued, the better the housing situation. The relationship between the degree of disability and housing conditions is observed on the brink of statistical significance $(p=.089)$. The direction of relationship suggests that the lower the degree of disability, the better the housing situation reported by the respondents.

Moreover, the data given in Table 9 indicate that there is a statistically significant relationship between the assessment of the financial situation and the age of the respondents $(p=.038)$. The relationship between the aforementioned variables is characterized by the moderate strength (Kendall's tau $b=-.163$ ). The correlation analysis also shows that younger respondents better assess their financial situation. The relationship between socio-demographic variables such as education $(p=.060)$, place of residence $(p=.078)$ and disability degree variable $(p=.079)$ are on the brink of statistical significance.

Furthermore, the correlation analysis shows the statistically significant relationship between place of residence $(p=.001)$ and disability degree $(p=.004)$. In both cases the strength of association is quite strong (Kendall's tau $b=-.277$, respectively). Based on the aforementioned analyses, a conclusion may be drawn that town residents find their labour market situation better. Finally, the correlation analysis also indicates that the lower the degree of disability the respondents have, the better their assessment of their situation on the labor market.

Table 10. Analysis of the correlation between the 'socio-economic situation of people with disabilities' dependent variable - synthetic approach, and socio-demographic and disabilityrelated variables

\begin{tabular}{|c|c|}
\hline Name of variable & Socio-economic situation - synthetic approach \\
\hline \multirow[t]{2}{*}{ Gender } & $p=.803$ \\
\hline & Kendall's tau $b$ coefficient $(-.019)$ \\
\hline \multirow[t]{2}{*}{ Age } & $p=.028$ \\
\hline & Kendall's tau $b$ coefficient $(-.152)$ \\
\hline \multirow[t]{2}{*}{ Education } & $p=.024$ \\
\hline & Kendall's tau $b$ coefficient $(.154)$ \\
\hline \multirow[t]{2}{*}{ Place of residence } & $p=.095$ \\
\hline & Kendall's tau $b$ coefficient ( .126$)$ \\
\hline \multirow[t]{2}{*}{ Kind of disability } & $p=.823$ \\
\hline & Kendall's tau b coefficient (.017) \\
\hline \multirow[t]{2}{*}{ Period for which disability certificate was issued } & $p=.149$ \\
\hline & Kendall's tau $b$ coefficient $(-.104)$ \\
\hline \multirow[t]{2}{*}{ Degree of disability } & $p=.125$ \\
\hline & Kendall's tau $b$ coefficient $(-.114)$ \\
\hline
\end{tabular}

Source: authors' own compilation based on surveys. 
Table 10 shows that the socio-economic situation of people with disabilities in the synthetic approach is significantly more affected by the socio-demographic characteristics of the respondents than their disability-related characteristics.

A detailed analysis of the variables included in the synthetic variable, the socioeconomic situation (cf. Table 9) leads, however, to the conclusion that the specific variable related to the degree of disability has a statistically significant effect on the assessment of the situation of the respondents on the labor market and, to some extent, on the housing situation and assessment of the financial conditions of persons with disabilities.

\section{Conclusions}

The assessment of the living conditions by disabled persons themselves is a very complex task due to the large number of mutually impacting factors.

The use of questionnaire surveys among people with disabilities seems to be justified because of the fact that while the problem of the quality of life, socioeconomic situation or material conditions are the subject of many studies, reports and studies in the literature on the subject, it is used to a very small extent for persons with disabilities. On the other hand, collecting data using the questionnaire in paper form made it possible to quickly reach a significant group of respondents potentially interested in the research problem. The presented analysis concerns the study of the socio-economic situation of people with disabilities.

The analyses carried out showed a significant degree of similarity in the social and living situation of the respondents in terms of place of residence. The study confirmed that disabled persons living in rural areas assess their housing conditions and financial situation of their families higher than those living in towns. On the other hand, disabled persons living in urban area assess their situation on the labor market higher. The correlation analysis also shows that a lower degree of disability coincides with the respondents' higher assessment of the labour market situation, which provides opportunities for social integration and may considerably prevent social exclusion. Such respondents also assessed higher their housing conditions.

Therefore, H1 was rather positively verified (Siedlecka and Smarzewska, 2013, pp. 155-166).

The statistically significant impact of the place of residence, disability degree, and education on the socio-economic conditions of respondents was observed. Place of residence (town/village) and degree of disability have the largest impact on the diversification of socio-economic conditions. The diversification of socio-economic conditions is slightly less modified by the level of the respondents' education. The respondents' age and location of the occupational therapy workshops have only a slight impact on the diversification of the socio-economic conditions. Thus, it may be concluded that socio-demographic characteristics affect socio-economic 
conditions significantly more than disability-related variables. This is the reason why $\mathrm{H} 2$ should be rejected.

\section{References}

Antczak, R., Grabowska, I. and Polańska, Z. (2018). Podstawy i źródła danych statystyki osób niepełnosprawnych. Wiadomości statystyczne, 2, (681), 21-43.

Atkinson, B. and Mariel, E. (2010). Income and living conditions in Europe. Eurostat, European Commission. Retrieved from https://ec.europa.eu/eurostat/documents/3217494/5722557/KS-31-10555-EN.PDF

Bakula, M. A., Kovacevic, D., Salirar, M., Palijan, T. Z., and Kovac, M. (2011). Quality of life foreign people with phyisical disabilities. Coll. Antropol, (35), 2, 247-253.

Bedyńska, S., and Brzezicka, A. (2007). Praktyczny poradnik analizy danych w naukach społecznych, Warszawa: SWPS Academica.

Borowiecki, P. (2016). Jakość życia osób z niepełnosprawnością i ich rodzin w perspektywie zewnętrznej i wewnętrznej - przegląd wybranych badań, Niepetnosprawność - Zagadnienia. Problem, Rozwiązania, 3(20), 81-91.

Borys, T. (2001). Jakość życia jako kategoria badawcza i cel nadrzędny. In A. Wachowiak (Ed.), Wybrane problemy jakości. Poznań: Wydawnictwo Fundacji "Humaniora".

Brantley, A., Huebner, E. S., and Nagle, R. J. (2002). Multidimenstional life satisfaction reports of adolescents with mild mental disabilities, Mental Retardation, (40), 321-330.

Field, A. (2005). Discovering statistics using SPSS, London, New Delhi: Sage Publication.

Firlit-Fesnak, G., and Męcina, J. (2018). Polityka społeczna, Warszawa: PWN.

Grzega, U. (2012). Poziom życia ludności w Polsce - determinanty i zróżnicowania, Katowice: Wydawnictwo Uniwersytetu Ekonomicznego.

Heffner, K., and Klemens, B. (2012). Warunki życia i aktywność społeczno-gospodarcza mieszkańców obszarów wiejskich (na przykładzie województwa opolskiego). Barometr Regionalny, 4(30), 81-88.

Howell, D. C. (2006). Statistical Methods for Psychology. Duxburry: Thomsoson Learning, Pacific Grove.

Incomes and living conditions of the Polish population - EU research report - SILC 2027. (2019). Warszawa: GUS. Retrieved from https://stat.gov.pl/en/topics/living-conditions/living-conditions/ income-and-living-conditions-of-the-population-of-poland-report-from-the-eu-silc-survey-of2017,1,10.html

Janoś-Kresło, M., Komorowska, O., Skalska, T., and Słaby, T. (2016). Determinants of quality of life for families with children with disabilities. In Entrepreneurial and consumer behaviours in families upbringing up children and young people with disabilities. Warszawa: SGH Publishing House.

Komorowska, O., Kozłowski, A., and Słaby T., 2019, Comparative analysis of poverty in families with a disabled child and families with non-disabled children in Poland in the years 2014 and 2016. Statistics in Transition New Series, 20(3), 97-117.

Kowalczyk, O. (2018). Ćwierć wieku reformowania systemu zabezpieczenia społecznego osób niepełnosprawnych w Polsce - wybrane aspekty. Wrocławskie Studia Politologiczne, (24), 66-79.

Koza, A. (2016). Niepełnosprawni i ich konkurencyjność na rynku pracy. Studia Ekonomiczne. Zeszyty Naukowe Uniwersytetu Ekonomicznego w Katowicach, (293), 23-36.

Living conditions in Europe - 2018 edition, Eurostat. (2018). Retrieved from https://ec.europa.eu/ eurostat/documents/3217494/9079352/KS-DZ-18-001-EN-N.pdf/884f6fec-2450-430a-b68d$\mathrm{f} 12 \mathrm{c} 3012 \mathrm{f} 4 \mathrm{~d} 0$

Material and income situation of households of retirees and pensioners and households with older people aged 60 or more in 2016. (2017). Warsaw: GUS. Retrieved from https://stat.gov.pl/files/ gfx/portalinformacyjny/en/defaultaktualnosci/3305/2/11/1/household_budget_survey_in_2016.pdf 
Michalska-Żyła, A., and Starosta, P. (2016). Społeczny potencjał odrodzenia miast poprzemystowych, Łódź: Wydawnictwo Uniwersytetu Łódzkiego.

Mockeviciene, D., and Savenkoviene, A. (2012). Aspects of life quality of persons with physical disabilities. Social Welfare Interdisciplinary Approach, 2(2), 84-93.

Morisse, F., Vandemaele, E., Claes, C., Claes, L., and Vandevelde, S. (2013). Quality of life in persons with intellectual disabilities and mental health problems: An explorative study. Hindawi Publishing Corporation The Scientific World Journal. Retrieved from http://dx.doi.org/10.1155/2013/491918

Nowojczyk, M. (2010). Przewodnik po statystyce dla socjologów. Kraków: SPSS Polska.

Otrębski, W. (2007). Interaktywny model rehabilitacji zawodowej osób z upośledzeniem umysłowym. Lublin: Wydawnictwo KUL.

Panek, T. (2016). Jakość życia od koncepcji do pomiaru. Warszawa: Oficyna Wydawnicza SGH.

Piasny, J. (1993). Poziom i jakość życia ludności polski oraz źródła i mierniki ich określania. Ruch Prawniczy, Ekonomiczny i Socjologiczny, LV, 2, 73-93.

Polak, Z., and Pomarańska, E. (2006). Percepcja własnej sytuacji a poczucie jakości życia osób z upośledzeniem umysłowym. In Z. Polak (Ed.), Jakość życia osób niepetnosprawnych i nieprzystosowanych społecznie. Lublin: Wydawnictwo UMCS.

Regionalne zróżnicowanie jakości życia w 2018 r. Wyniki badania spójności społecznej 2018. Informacje sygnalne. (2018). Warszawa: GUS. Retrieved from https://stat.gov.pl/obszary-tematyczne/ warunki-zycia/dochody-wydatki-i-warunki-zycia-ludnosci/regionalne-zroznicowanie-jakoscizycia-w-polsce-w-2018-roku-wyniki-badania-spojnosci-spolecznej-2018,31,1.html

Rutkowski, J. (1990). Badania jakości życia (synteza). In Jakość życia i warunki bytu (pp. 33-34). Warszawa: GUS.

Sadowska, S. (2006). Jakość życia uczniów z niepetnosprawnościa intelektualna w stopniu lekkim, Kraków: Oficyna Wydawnicza "Impuls".

Siedlecka, A., and Smarzewska, A. (2013). Warunki mieszkaniowe jako miernik jakości życia osób niepełnosprawnych. Zeszyty Naukowe $S G G W$ w Warszawie. Ekonomika i Organizacja Gospodarki Żywnościowej, (202), 155-166.

Smoleń, R., and Sękowski, A. (2008). Ocena poczucia jakości życia u osób z upośledzeniem umysłowym w kontekście zmiennych psychospołecznych. In P. Francuz, and W. Otrębski (Eds.), Studia z psychologii w KUL. Lublin: Wydawnictwo KUL.

Stiglitz, J. E., Sen, A., and Fitoussi, J. P. (2009). Report by the Commission on the Measurement of Economic Performance and Social Progress. Retrieved from http:/ /citeseerx.ist.psu.edu/viewdoc/ download?doi=10.1.1.215.58\&rep=rep1\&type $=$ pdf

Szarfenberg, R. (2017). Prawo do odpowiednich warunków życia i ochrony socjalnej: art. 28 Konwencji o prawach osób niepelnosprawnych. Raport tematyczny (Version of 15.02.2017. Project "Implementation of Convention on the Rights of Disabled People - Common Cause." Project run under Knowledge, Education, Development OP 2014-2020. Priority Axis II. Effective public policies for the labor market, economy, and education. Measure 2.6 High quality policy for the social and vocational inclusion of the disabled persons). Retrieved from http://www.pfon.org/wdrazanie-konwencji-o-prawach-osob-niepelnosprawnych-wspolna-sprawa

Szymczak, W. (2010). Podstawy statystyki dla psychologów. Warszawa: Difin.

Wyszkowska, Z., and Gotowska, M. (2013). Poziom i jakość życia w dobie kryzysu. Bydgoszcz: Wydawnictwo Uczelniane Uniwersytetu Technologiczno-Przyrodniczego.

Zawiślak, A. (2011). Jakość zycia osób dorostych z niepetnosprawnościa intelektualna. Warszawa: Difin. 